\title{
A ILUSTRAÇĀo NO PODER: CARLOS III
}

\section{Earle Macarthy Moreira*}

Embora o ponto de partida do movimento espiritual característico do século XVIII europeu, conhecido como "Ilustração", encontre-se na Inglaterra, bem perfilado em Locke (1632-704). grande analista e crítico severo da obra de Descartes, mas, em política, o grande inspirador do corpo ideológico da "Declaração da Independência dos Estados Unidos" e da "Declaração dos Direitos do Homem e do Cidadão", - é da França que as idéias ditas "ilustradas" se projetam sobre toda a Europa.

A Espanha, apesar dos esforços em contrário da Inquisição, não escapou a seus influxos. Toda uma literatura destinada à valorização de uma atitude crítica universal, apregoadora do triunfo da razão e da negação da verdade revelada, incentivadora da busca da felicidade terrenal, otimista, cientificista e satírica, saída das penas de Montesquieu, de Voltaire, de Diderot, de Helvécio e outros, mas, sobretudo, de Rousseau, com o Contrato Social e o Emílio, entrou em território espanhol, para desespero dos censores, que profligan, como Frei Rafael Vélez o "pus" e os estragos causados por ela: “...uma rebelião dos povos contra a religião, (...), uma imoralidade, uma corrupção, uma peste que contraímos do comércio com a França, da leitura de seus livros". ${ }^{1}$

Se levarmos em conta, ainda, que o século XVIII na Espanha assiste o ingresso e a consolidação da nova dinastia dos Borbón, marcando assim uma bem visível presença francesa na vida política, que ia, no princípio, das diretrizes pessoalmente dadas por Luís XIV a seu neto Filipe de Anjou, no que tange à administração interna do país suas relaçōes exteriores, inclusive propondo as pes- 
soas capazes de executá-las, até à presença insólita e fiscalizadora do embaixador da França nas sessões de despacho, não é de admirar que o chamado "afrancesamento" se haja feita sentir de forma bem marcada.

O já citado Frei Rafael Vélez, capuchinho, que foi nada menos que arcebispo de Santiago e "caballero gran cruz de la Real y Distinguida Orden de Carlos III", em libelo de significativo título - "Preservativo contra a irreligião, ou os planos da Filosofia contra a religiảo e o Estado, realizados pela França para subjugar a Europa, seguidos por Napoleão na conquista da Espanha, e dados à luz por alguns de nossos sábios em prejuízo de nossa pátria" - publicado em 1825, em plena restauração do absolutismo fernandino, não deixa por menos: "A libertinagem, a imoralidade, o luxo, a efeminação, aqueles vícios peculiares característicos dos franceses, em não pequena parte se expandiram entre nós. O nosso gosto chegou a viciar-se de tal modo que nada agradava a não ser o que fosse originário da França. Gêneros franceses, modas da França. Seus costumes, suas maneiras, saudar à francesa, andar à parisiense, este era o cuidado dos nossos petimetres, a solcitude de muitas senhoras, e como um prurido geral de todo espanhol que se quis fazer visível, afetando política e saber. As viagens à França eram reputadas entre alguns de nossos nobres como um dever, e o educar nossos jovens em seus colégios como um meio necessário para adquirir a ilustração de que dizem se carece em Espanha e que somente se podia aprender em Tolosa, Montpelier e Paris. Deste modo, a sua língua chegou a vulgarizar-se entre nós. Nossos meninos não sabiam o catecismo e já falavam o francês. O belo sexo se dava tinturas nos conhecimentos dessa língua e reputava como um donaire misturar nas conversaçōes mais familiares algum termo francês. A nossa língua harmoniosa, doce, rica, chegou a alterar-se com a nomenclatura de suas vozes, que apenas podemos agora distinguir. A devoção também afrancesou-se. Os livros nas mäos das senhoras, se forem ao templo e assistirem ao santo sacrificio da missa, as fazem preferir (como às francesas mais devotas) a leitura à oração". ${ }^{2}$

O Diário de Barcelona, de 10 de novembro de 1792, dá a seu modo um registro do fenômeno: "Há homens que nada apreciam se nāo o lêem em pena francesa, como se o engenho e sua cultura fossem patrimônio reservado à nação vizinha. Por que houve na França um Bossuet, um Alembert, um Jussieu e um Buffon, crêem alguns muito satisfeitos que só naquele reino há teólogos, matemáticos, jurisconsultos, botânicos e naturalistas. Não refletem que o 
mesmo terreno que produz uvas e pêssegos também dá espinhos, cardos e ervas daninhas". ${ }^{3}$

Barcelóna, sabidamente era a cidade mais progressista da Espanha, em todos os sentidos, e se lá essa espécie de "colonialismo cultural", como diríamos hoje, causava coceira, o que não dizer da Espanha mais conservadora!

Assim como assim, o fato é que descontada a mania de imitação, que leva o mordaz Torres Villarroel ${ }^{4}$ a classificar seus compatriotas de "micos da espécie", que "sem consultar a razão, enamorados das superfícies, qualificam de melhorias às estravagâncias", a produção intelectual francesa invadia a terra dos Reis Católicos, com títulos falsos, encadernações trocadas, nas dobras dos chapéus, como papel de embrulho, em tiras, em resumos, e era lida, avidamente, às escondidas.

Já se pode perceber que impõe-se uma distinção bem marcada entre a avalanche da "moda", alterando usos e costumes das classes altas até raiar o ridículo, e o influxo positivo, renovador, progressista, que advém da mesma fonte e que coincide com o crescimento da burguesia, cujo sucesso econômico é definitivo nesse século e cujos empreendimentos passavam por cima da opinião tradicional sobre a iniqüidade da usura e a santidade da pobreza.

Pobreza, aliás, que chegará a causar molestar físico ao "ilustrado" Meléndez Valdez: "Eu mesmo, que reparto agora (em Zamora) uma esmola de pão e dinheiro a várias paróquias, como membro da junta, apesar das maiores precauçõs, sinto-me envolto (...) nesta massa de ar pestilencial e fétido que a mendicidade carrega consigo e que embarga e debilita minha respiração..."5

Demonstrativo cabal do trágico desconcerto social da Espanha, neste século, pode ser dado pelo elevadíssimo número de mendigos existentes no país. Segundo Campomanes eram cerca de 140.000, para uma população global de mais ou menos 8 milhōes de indivíduos. ${ }^{6} \mathrm{O}$ cortejo de roubos e crimes de toda a ordem, que por força acompanhava essa situação, levantava clamores por toda a parte, criava uma sensação de insegurança aflitiva para o povo e apresentava-se como problema dos mais sérios para as autoridades.

$\mathrm{Na}$ análise da questão, os "ilustrados" dividiam-se. Para Cabarrús, por exemplo, o motivo principal da miséria era a falta de trabalho. Em uma de suas Cartas, é taxativo: “Quantos pobres temos? Poder-se-á responder, sem violentar a inteligência, que quase toda a nação o é, e seria muito mais fácil enumerar os pouquíssimos que tudo possuem, do que o total dos que nada têm".? 
Mas, a falta de trabalho, por sua vez, tem causas próprias, entre as quais avulta a questäo da propriedade, - tema de primeira grandeza para os "ilustrados".

Ignácio de Asso, em 1798, na História de la economia política de Aragón, chega à seguinte conclusão: "A reunião de muitas e grandes herdades em uma pessoa é um dos maiores obstáculos para os progressos da lavoura... Quanto maior é a divisảo das terras, tanto mais se multiplicam os efeitos saudáveis do trabalho e dos meios de subsistir". 8

No Tratado de la Regalía de amortización..., de Campomanes, que foi fiscal e Governador do Conselho de Castela em tempos de Carlos III e Carlos IV, são equacionados os principais pontos das críticas sobre o sistema que regia a propriedade na Espanha: Primeiro, o enorme encarecimento da propriedade agrária, devido à escassez no mercado imobiliário; segundo, o seu ínfimo rendimento; e, terceiro, a falta de interesse na aplicação de capitais na propriedade territorial, com fins especulativos ou práticos.

O fato é que seguia vigente a estrutura feudalizante da propriedade agrária, com o gravoso sistema de "mãos mortas", que abarcava e imobilizava grande parte do solo. Eram as propriedades dos conventos, igrejas, confrarias, colegiados, catedrais ou bens comunais. Junte-se a isso a situação da propriedade privada, que tendia a estancar-se em morgadios ou vinculaçöes à uma mesma família. Em certas províncias eram raríssimas as propriedades livres individuais. $\mathrm{Na}$ Galícia, por exemplo, o grosso das terras de cultivo, de proprie: dade do estado eclesiástico e alta nobreza, estavam arrendadas e subarrendadas. Em conseqüência: "Os camponeses cultivadores de terra formavam oitenta por cento da populaçäo ativa. Estes, depois de pagar dízimos, rendas ou direito foral, encargos senhoriais e impostos à Real Fazenda, viviam no limite da subsistência. $\mathrm{O}$ absentismo da alta noreza e o destino que esta dava a seus ingressos, do mesmo modo que os eclesiásticos, permite compreender que não se realizassem inversões no setor agrário".9

Tal situação provocou violenta reação dos economistas ilustrados, como foi o caso de Jovellanos, no famoso Informe sobre a lei Agrária (1784): "Ninguém aliena suas terras a não ser no caso de extrema necessidade, porque não haveria a esperança de poder voltar a adquiri-las. Em troca, o poder das corporações e familias amortizantes cresce necessariamente com a amortização, por que quanto mais adquirem mais meios têm para adquirir e por que não podendo alienar o que uma vez adquiriram, o progresso da sua 
riqueza deve ser indefinido. Tais são as razōes que conduziram a propriedade nacional à posse de um escasso número de indivíduos". 10

É interessante constatar que abriu-se, na segunda metade do século, acalorado debate sobre a natureza que devia tomar a propriedade popular: se seria coletiva, com o estabelecimento de coutos comunais e trabalho cooperativo - tese de Aranda, Floridablanca e Olavide - ou individual, tese de Jovellanos, cujas idéias foram aceitas nas cortes de Cádiz e vitoriosas no século XIX, com a desamortização civil.

As sugestôes práticas, que os ministros "ilustrados" apresentaram à Realeza, foram no sentido de permitir a venda das casas arruinadas ou ameaçadas pela ruína, dos patrimônios em morgadio, e de impor um imposto de $15 \%$ sobre os mesmos morgadios. Tudo isso visando passar à circulação geral um número regular de bens vineulados, e como seria de esperar-se, com grande resistência da nobreza, que via em sua propriedade imobiliárias o "rescaldo" sobrante de sua influência social. Era uma das poucas coisas que a burguesia arrivista e agressiva não lhe havia ainda tirado.

No exame da pobreza e suas mazelas, então, os "ilustrados" dividiam-se. Enquanto uns seguiam a vertente que ia dar na temática da propriedade da terra, outros tomavam diversos rumos. É o caso de Bernardo Ward, em 1762, no Proyecto económico en que se promueven varias providencias dirigidas a promover los interesses de España com los medios y fondos necesarios para su plantificación, o qual, com visão mais sociológica, desmonta uma pretendida "frugalidade" inata do espanhol: "Há certas virtudes morais mal entendidas, que são vícios políticos e servem de grande estorvo à indústria. A frugalidade dos nossos espanhóis é em grande parte causa da sua desídia: quem se contenta com pouco no comer e no vestir, se ganha em três dias com que viver seis, não trabalhará senão os três".

Em outra passagem, dá uma explicação pitoresca para a veneração da pobreza e o mal da mendicância: "A humildade de um religioso que, podendo ter as suas conveniências, se sujeita a viver de esmola, é sem dúvida de muito exemplo e digna de estimação; mas, quando vê o menino que sua mãe ao dar a esmola ao irmão beija-lhe a mão, aquilo de ver juntas a mendicidade e a veneração engendra nos ânimos, desde a tenra idade, uma impressão que, em gente rude, que nāo sabe distinguir a pobreza religiosa da mendicidade culpável, os inclina insensivelmente à vida ociosa. Nos países 
onde não há religiosos mendicantes nem peregrinos, não tendo a pobreza aspecto algum favorável, o horror que a gente plebéia tem a tal estado é um poderoso incentivo a favor da indústria". ${ }^{11}$

Coincidem, tanto ele como Campomanes, em que os verdadeiros necessitados, na multidão dos mendigos, é bem menor que o total. Ward assegura que "quem quer que dê esmola aos que acodem à sua porta, a dará a quatro vagabundos por um verdadeiro pobre"; para Campomanes, dos cento e quarenta mil mendigos existentes, somente 30 mil eram verdadeiros indigentes: os dois dão, como se vê, quase que a mesma proporçäo. ${ }^{12}$

Há, no caso, um evidente problema de mentalidade, que mexe com o discernimento dos "ilustrados" e que leva-os, com o correr do tempo, a preconizar verdadeiras "reformas de base", para usarmos um termo tão a gosto do momento atual. Para lá chegar, era preciso saber, a contado, o real estado da nação. Daí a insistência com que se multiplicam os recenseamentos e as tabulações de dados.

Os resultados conhecidos delineiam uma fisionomia nacional preocupante: em 1787, por exemplo, havia 191.116 eclesiásticos, 480.587 fidalgos e 500.000 domésticos, isto é, mais ou menos 1.150 .000 pessoas viviam sem produzir. $30 \%$ da população adulta masculina não produzia absolutamente nada: $20 \%$ possuía o grosso da propriedade territorial, e apenas $22 \%$ da massa camponesa, que constituía $60 \%$ da população global, era proprietária das terras em que trabalhava.

A população năo crescia de acordo com o ritmo europeu, apesar da grande força de procriação liberada com o difundido costume dos casamentos precoces, por que era anulada, em grande parte, pela ignorância generalizada das mais comezinhas noçöes de higiene pública e privada, o que levava a uma exagerada mortalidade infantil. P. Ex.: em 9 povoados de Aragón, (Bujaraloz, Farlete, Gelsa, Quinto, Valpalmas, Villanueva de la Huerva, Monsalbarba, Peracense e Tauste), nasceram, entre 1786 a $1790,1.614$ crianças, das quais morreram, nos sete primeiros anos, $548 .^{13}$

A esperança de vida na segunda metade do séc. XVII espanhol era de 24 anos! Conforme Gonzalo Anes: "O demógrafo italiano Levi Bacci analisou a distribuição, por idades, da população espanhola segundo o censo de 1768-1769 e concluiu que não é possível aceitar crescimentos superiores a $1 \%$ ao ano desde 1717 , já que, de ser assim, a esperança de vida ao nascer teria que haver sido, em 1768, de uns 40 anos, coisa que, na Espanha, só se alcançou entre 1911 e 1920 ". ${ }^{14}$ 
Escritores da época - Ignacio de Asso (Historia de la economía política de Aragón), Campomanes (Discurso sobre la educación de los artesanos), Torres Villarroel (Sueños), Don Ramón de la Cruz ("Manolo", no Teatro Selecto) - criticam a situação dos trabalhadores urbanos, com sua despreocupação pela poupança, seu costume inveterado de consumir os magros salários no carteado e no trago das tabernas. Faltasse o pão em casa para a familia, mas não faltasse ele às touradas. Maltrapilho, sujo e soberbo!

Modera-se a severidade, porém, se levado em consideração que na época de Carlos III, nas classes da mais alta estirpe, a chamada "roupa interior" ou "de baixo" não era tão abundante como agora; geralmente, as senhoras e senhoritas costumavam mudála, uma vez por mês! ${ }^{15}$

A princesa Isabel de Orleans e Bragança, Condessa de Paris, no seu saboroso livro de memórias, (De todo coração), dá-nos uma boa descrição dos confortos da residência do Príncipe Czartoryski, em Paris, onde ela chegou a morar, quando adolescente: "A Áté 1932, o palácio Lambert não tinha nem eletricidade nem banheiros. Perdão! Havia o dos Czartoryski, mas nunca soube onde ficava. Até o meu casamento, em todo o caso, subiam, para nós jarros de água fervendo que jogavam numa banheira de zinco colocada num corredor escuro, e durante anos todos os cinco tomávamos banhos sucessivamente. O primeiro tomava um banho quente e mais limpo e o último um banho momo e mais sujo. A cerimônia era alternada..."16 Como se vê, tudo é mais relativo...

Mas, voltando ao ponto, impöe-se uma pergunta: as chamadas elites dirigentes de então poderiam assumir um papel renovador da vida social do país? Os depoimentos dos diplomatas estrangeiros acreditados em Madrid são coicidentes com os dos "ilustrados": nāo!

A alta nobreza caracterizava-se pela indigência intelectual e pela beatice supersticiosa e, o que é curioso, por um plebeísmo assumido. Ortega y Gasset, na análise psicológica dessa aristocracia em seus Papeles sobre Velázquez Y Goya, assevera: "(As classes superiores) somente se sentiam felizes quando abandonavam suas próprias maneiras e se saturavam de plebeísmo. Não se trate de minimizar o fato: foi o plebeísmo, o método de felicidade que acreditaram haver encontrado nossos antepassados do século XVIII".

As descriçōes abundam. O Marquês de Aubeterre, embaixador da França, descreve o opulento Duque de Bejar como "inteligência curta e devoto rematado". Jovellanos, o comedido Jovellanos, define 
o Conde de la Vega como um pobre de espírito, que fala de tudo e não entende de nada. O Marquês de Ciriñuela é um "um velho torto e animalesco: é um homem que gastou 80.000 reais para que fossem postas duas velas para um santinho de sua capela; a Marquesa, uma aldeã simplória". E por aí afora. ${ }^{17}$

O clero, em geral, não ficava melhor parado. Torres Villarroel, (Vida, p.131-133) escreve sobre os "curas bravios, sacerdotes casados, que mantêm nos povoados e aldeias acanhadas cinqüenta anos de criada de duas serventias e, de pais de almas, se fazem pais de corpos, se mandam para a Corte acossados por seus bispos e provisores, abandonam de todo a sua consciência e a sua freguesia, se vestem de curto, rabāo e desenfadado, e passam a vida sem lembrar-se de sacramento nenhum". ${ }^{18} \mathrm{O}$ nível intelectual desse setor era, pelo geral, medíocre. A Teologia não se renovava em relação ao século anterior e se perdia na puerilidade de disputas estrambóticas. Tudo ao sabor de uma oratória sacra impregnada de um barroquismo pseudo-poético, que foi arrastado ao mais atroz ridículo pelo Pe. Isla, (e lhe valeu a Inquisiçāo!), no seu irreverente Fray Gerudio, cujo sermão no refeitório do convento é hoje peça antológica, em matéria de "non sense": "Não é de menos valor a cor verde por não ser amarela, que o azul por não ser encarnado: $D o m i$ nus, o altitudo divitiarum sapientiae Dei; como nem tampouco faltaram as cores a ser oráculo da vista, nem as palavras na fé dosouvidos como disse Cristo: Fides ex auditu; auditum autem per verbum Cristi. Nasceu Ana, como assegura minha fé por ouvir dizer, de cor vermelha; por que as cerúleas ondas de seu funesto sentir a fizeram fortemente palpitar no útero materno: Ex utero ante luciferum genuit te. A esse, pois, anjo transparente, diáfana inteligência e objeto especulativo da religiāo mais acre, consagra esta estática e fervorosa plebe estes cultos hiperbólicos, pois, tem, como ali se vê, formoso e airoso vulto: Vultum tuum deprecabantur omnes divites plebis. Deixo-me de exórdios e vou ao assunto, embora tão principal. Comece, pois, o curioso a perceber. Qui potest capere, capiat". 19

Quando os jesuítas foram expulsos, entre as razōes declaradas e as escondidas, não consta, por certo, o papel de críticos da vida relgiosa e da péssima formação do clero regular e secular. Antes de tomar tal medida, o Governo consultou os prelados espanhóis e 5/6 deles aconselhou a expulsão, sem padecer coação alguma! ${ }^{20}$

A linha da exposição, nos endereça agora a um ponto fundamental da "Ilustração" espanhola: o seu moralismo pedagógico. 
Os "ilustrados" estavam convencidos de que o homem, somente por ignorância de seus verdadeiros interesses, é mau. A "ilustração" tinha, pois, que ser vivida como uma verdadeira "tarefa pedagógico-moral", e isto também no que diz respeito a uma outra dimensão do viver: a econômica. Por isso mesmo o que importava fomentar era uma forma de vida consistente em "saberes úteis". ${ }^{21}$

Era preciso lutar por esses "saberes úteis", que fazem bons médicos, físicos e químicos; que servem para criar indústrias, fábricas e artes; para beneficiar minas, construir estradas, canais, pontes e tudo o mais que redunde em utilidade pública.

Entenderam que a educação não podia continuar a ser pura obra de caridade, dispensada pelas ordens religiosas, e que o Estado tinha o dever de se fazer presente nesse campo. Era preciso reformar as velhas e esclerosadas universidades; desenvolver novos ramos acadêmicos; e, principalmente, incentivar a criação de escolas técnicas e tornar o ensino primário - ponto chave de qualquer mudança social - acessível a todos. "Pois, evidentemente, não bastava ministrar uns "saberes úteis", era preciso atingir um objetivo muito mais ambicioso: a mudança de mentalidade, e com ela, a das atitudes fundamentais". 22

Como bem observa José Luis Aranguren, em "La moral social española en el siglo XIX”: "...denominamos a Ilustração de uma nova "forma de vida". Com efeito, era necessário transformar a tradicional mentalidade espanhola, fidalga, guerreira e conquistadora, muito mais dada às "façanhas" que à "indústria", mais amiga dos "trabalhos" que do trabalho, improdutiva, mas solene e muito cuidadosa das aparências e reverências, generosa e magnificente, reguladora dos gastos não pelos ingressos, mas sim pelas exigências da "representação", em uma mentalidade completamente diferente: aplicada na produção de bens úteis, empreendedora, mas já não de façanhas, mas sim de indústrias, obras públicas e relações comerciais, capaz de economizar, isto é, de acumular capital para reinverter, suscitar, assim, uma economia em crescimento ou expansão, que não se limitasse apenas a atender a uma demanda fixa, tradicional, quietista, senão que, ao solicitar nova demanda de bens, se obrigasse a si mesma ao aumento da produção e, com isto, a nova demanda de trabalho e aumento de salários". ${ }^{23}$

E por pensar assim é que a fração dominante dos "ilustrados" adotou com decisäo o liberalismo econômico, preconizado por Adam Smith. 
Ninguém nega a influência francesa em todo esse processo. Mas, todos quantos, nestes últimos vinte anos, vêm investigando a matéria, estāo coincidindo em um ponto: é o de que mais que um "afrancesamento", o que há mesmo é uma "europeização". A França não é o exclusivo objeto da admiração espanhola, nesse tempo. A Holanda e a Inglaterra são constantemente citadas como exemplares em matéria de navegação e comércio. E, note-se que isso se dá em um período de intensa anglofobia.

José María Sánchez Diana, em El despotismo ilustrado de Federico el Grande y su influencia en España, já em 1954, nos comprova, com fontes do século XVIII, o impacto ocasionado na Espanha pelas reformas e realizações daquele monarca. ${ }^{24}$ Diversas outras influências transparecem, nas mesmas fontes. E, sob este ângulo, faz sentido o que escreveu Campomanes quanto ao critério de equilíbrio e medida que devia presidir a recepção desse caudal: "Assim, o que importa na ordem política a uma naçâo é tomar exemplo das mais aplicadas, instruir-se no que ignora e começar dentro dela toda a indústria de que carece e seja acomodada ao bem-estar do país e suas possibilidades". ${ }^{25}$

Pouco antes, havia Campomanes cortado caminho aos que atribuiam, de forma simplória, os problemas nacionais à maquinaçāo das potências estrangeiras e nos lega uma lição magistral: "Não devemos atribuir a outras nações aquilo que depende de causas conhecidas, que influiram na destruição da nossa indústria e incentivaram a estrangeira. É muito prejudicial prorromper em declamaçöeś que nada remediam. Corrijamo-nos nós próprios, tomando dos outros países aqueles conhecimentos que nos sejam mais vantajosos". ${ }^{26}$

Em 1759 - início do reinado de Carlos III - o Marquês de Aubeterre havia visto a Espanha como um país despovoado, sem indústria, nem boa fé, com quase nada de polícia e pouca justiça. Sem caminhos, nem rios navegáveis, nem canais e poucas carrugagens: "Em uma palavra, pode-se dizer que este país leva, com relação a todos os demais, dois séculos de atraso, pelo menos". ${ }^{27}$

Descontados os exageros do ilustre embaixador, nāo se pode deixar de ver no esforço dos "ilustrados" um certo fundo dramático. Era uma carreira contra o relógio, pois a Revolução Francesa, e com ela a eclosấo de uma nova forma política, era já iminente. E eles tinham que reformar pedagogicamente, pela raiz, a mentalidade espanhola e as atitudes tradicionalmente hispânicas perante a vida: quebrantar o clericalismo, formar uma burguesia mal e mal esboçada e dar à luz as fontes de prosperidade da nação. Quer 
dizer, deviam realizar em dois ou três decênios, o que outros países haviam levado duzentos ou mais anos para levar a cabo. ${ }^{28}$

O reinado de Carlos III, neste contexto, foi um reinado chave e se destaca como aglutinador dos esforços anteriores. Até ali podem anotar-se soluçöes parciais, propostas para um que outro problema. $\mathrm{Na}$ época carolina, porém, pretende-se empeender um trabalho de conjunto. Os problemas são considerados em bloco. Os elementos parciais são aproveitados e utilizados num plano superior. E essa obra unitária, integradora e contínua, não escapa à inteligência daqueles que a estão realizando. ${ }^{29}$

Não é mais possível reduzir o papel de Carlos III, na Espanha, aos clichês correntes de um soberano bondoso, obcecado pela caça e manejado pelos ministros. Num país cujas instituições públicas eram praticamente inoperantes, a figura do rei assumia um papel proeminente e era para ele que se voltava o povo, em adesảo total, efusiva e enamorada. No regime absolutista, esta apertada aliança é que poderia - encontrado o homem certo - ensejar reformas, modemização, progresso. Com o rei tudo era possível; sem a vontade do rei, nada!

Na Espanha do século XVIII, é transparente o convencimento geral de que é preciso contar com o Trono, apoiar-se nele, influir sobre ele e movê-lo no sentido desejado; mas, jamais tocar num fiapo sequer de suas faculdades grandiosas, por que elas deviam ser utilizadas em benefício da empresa redentora.

Carlos III preencheu bem o espaço que lhe coube, naquele momento histórico. Ponderado, calmo e firme. Venerador do passado, veraz e simples. Tenaz e conseqüente. Administrador disciplinado e disciplinador, possuído do sentido cívico. Inteligência lenta, mas profunda e reflexiva, servida por excelente memória. Tais, em síntese, os principais traços de sua personalidade. ${ }^{30}$

Nascido em 1716, entre 1734 e 1759 reinou em Napoles. De 1759 a 1788, assumiu a Coroa da Espanha, lá chegando, portanto, como homem experimentado no ofício régio.

Como bem diz um de seus melhores e mais recentes biógrafos: "a raison mise en pratique, com ânimo de alcançar a virtude, constitui cabalmente a divisa que vai utilizar o monarca". ${ }^{31}$

Animava-o propósito de centralizar e uniformizar o caótico sistema administrativo espanhol. Na escolha de sua equipe de governo, duas diretrizes o inspiraram, invariavelmente: a intenção de que permanecessem no cargo o maior tempo possível e o propósito de que o matiz de cada um fosse compensado pelo outro, de tal 
modo que tendências e quereres diversos se equilibrassem. ${ }^{32}$ Só assim se explica a presença de homens tão diferentes, pela origem, pelo temperamento e pela atuação, como o foram Floridablanca e Aranda, entre seus mais chegados colaboradores.

Entre o que se pretendeu realizar nesse reinado e o que de fato se realizou, há um mundo de diferença: os resultados práticos, indiscutivelmente, ficaram muito aquém das expectativas.

O propósito de reformular a Espanha - comparada por Floridablanca, em suas Cartas político-econômicas, a uma velha casa sustentada à força de remendos, em que os mesmos materiais com que se pretende compor um lado derrubam o outro e que só se pode corrigir deitando-a por terra e reedificando-a de novo" - não deve ser julgado, diz Julián Marías, "pelo que parecem ser seus 'resultados e não o sâo, mas principalmente pelas conseqüências de sua sufocação". ${ }^{33}$

Foi uma tentativa que ficou incompleta e frustrada, se contemplada pelo ângulo da tentativa em si mesma. Mas, esta conclusão não impede, ao mesmo tempo, valorizar o quanto há nela de amplo, generoso e flexível, se contemplada levando-se em conta o país "real" sobre o qual se exerceu.

A véspera do segundo centenário de sua morte, forçoso é reconhecer no reinado de Carlos III um momento de auto-crítica das elites dirigentes espanholas, que despertam para uma contemplação mais realista de seu contorno. Momento de questionamento do "ser nacional", após demasiadamente longo período de aletargado narcisismo coletivo, em que o espelho das águas refletia, cada vez mais esmaecido, um passado de glórias e predomínios. Tentaiva de quebrar o transe hipnótico de um povo que fazia da obstinação e do orgulho uma trincheira contra a decadência. Abertura para novas posibilidades de vida, de frente e não de costàs para uma Europa trepidante de progresso material, de transformaçöes sociais e políticas.

E é nesse sentido que vale e se impōe a observação de Pedro Voltes: “...talvez o mais importante legado de Carlos III e seu tempo consista precisamente nessa idéia de “outra" Espanha praticável, que aí ficou, proposta à inquietação ulterior dos espanhóis como um constante estímulo, e que - constituída em perene possibilidade de exercício ideológico e de acicate de sentimentos - tem, desde logo, mais longa vida que as pontes, os canais, as escolas, os barcos e os castelos realizados pelo reinado". ${ }^{34}$ 
1VELEZ, Fray Rafael. Apología del altar y del trono, o Historia de las reformas hechas en España en tiempo de las llamadas Cortes, e impugnación de lagunas doctrinas publicadas en la Constitución, diarios y otros escritos contra la religión y el Estado, por don...; del Orden de Capuchinos, obispo de Ceuta; Madrid, (Cano), 1818.2v.t.I, pp.27-28; apud SARRAILH, Jean. La España Ilustrada en la Segunda Mitad del siglo XVIII. México, Fondo de Cultura Económica, 1957, pp.613-614.

${ }^{2}$ VELEZ, Fray Rafael. Preservativo contra la irreligion, pp.59-60; apud SARRAILH, op. cit., pp.380-381.

${ }^{3} \mathrm{O}$ Diario de Barcelona goza do raro privilégio de ser o jornal de propriedade privada mais antigo da Espanha. Seu primeiro número data de $1^{\circ}$ de outubro de 1792 e seu fundador foi o napolitano naturalizado espanhol Pedro Pablo Ussón de Lapezarán. No decurso da invasão francesa, porém, Ussón fez a política dos invasores e incompatibilizou-se com a maioria de seus leitores. Surgiu, então, por oposiçăo, outro Diario de Barcelona, espanholista, dirigido por Antonio Brusi Mirabent, autorizado pela Junta Suprema da Catalunha, cuja vida de jornalista é verdadeira aventura em tempo de guerra. É por isso que os catalāes costumam dar ao Diario o carinhoso apelido de "el Brusi". (v. APARICIO, Pedro Gómez. Historia del Periodismo Español: desde la "Gaceta de Madrid" (1661) hasta el destronamiento de Isabel II. Madrid, Ed. Nacional, 1969, pp.48-50; 67-69.

${ }^{4}$ TORRES VILLARROEL, Diego de. Sueños morales, visiones y visitas de Torres con don Francisco de Quevedo por Madrid. Corregidos y aumentados con La barca de Aqueronte, Residencia infernal de Plutón, Correo del otro mundo y cartas respondidas a los muertos, Sacudimiento de mentecatos, Historia de historias y El soplo de la justicia. Escrito por el doctor don...; Madrid, (en la imprenta de D.J. Doblado), 1791. apud SARRAILH, op.cit., p.381.

Misto de pícaro e intelectual, Villarroel, (1693-1770), nasceu e morreu em Salamanca. Toda a sua obra está marcada pela leitura desordenada, por insaciável curiosidade e charlatanesca audácia e, não obstante, raia a genialidade. É célebre, no gênero, uma viagem que fez a Portugal, onde apresentou-se, com sucesso, como ermitão, soldado, médico, dançarino e toureiro. De volta à Espanha, publicou uns almanaques de grande sucesso e que the renderam pingües ganâncias. Em 1726, foi eleito catedrático de Matemáticas na Universidade de Salamanca.

Foi protegido da Condessa de Arcos, da Duquesa de Alba e de outras figuras da alta nobreza. Aos cinqüenta e dois anos ordenou-se sacerdote e terminou seus dias no magnífico palácio de Monterrei, de propriedade do Duque de Alba.

Juan Antonio Tamayo, autor de seu verbete no Diccionario de Literatura Española, Madrid, Rev. de Occidente, 1972, 4a ed., assim o define: "Villarroel, pícaro e vagabundo em sua mocidade, escritor originalíssimo e estrafalário autor de prognósticos e livros pseudocientíficos, acaba por adquirir o ar grave do catedrático e do sacerdote, mas nunca o abandona de todo o ardor juvenil, que o leva a interferir belicosamente nas lutas da Universidade".

5 MELENDEZ VALDES, Juan. Discusos forenses. Madrid, (Imprenta Real), 1821, p.289; apud SARRAILH, op.cit., p.82. 
Foi o mais puro poeta de seu tempo. Nasceu em Badajoz (1754) e morreu em Montpelier (1817). Professor de Humanidades em Salamanca (1781), magistrado em Zaragoza (1789) e em Valladold (1791), passou a Madrid (1797) como fiscal da "Sala de Alcaldes de Casa y Corte". Por essa Época, tornou-se amigo de Jovellanos. Apesar de seu caráter tímido e vacilante, foi afamado orador forense. Afrancesado até a raiz dos cabelos, na crise de 1808 serviu ao rei José I como presidente da Instruçāo Pública. Devido a isso foi obrigado a emigrar para a França. A sua obra literária, na qual nẩo falta uma discreta sensualidade e um vago sentimentalismo, está ornada com certo sentido filosófico e humanitário, ao gosto do século.

${ }^{6}$ Citado por SARRAILH, op. cit., p.80; idem, BENEYTO, Juan. Historia Social de España y de Hispanoamérica. Madrid, Aguilar, 19.73, 2* ed., p.314; ib. VICENS VIVES, J. (Dir.). Historia de España y América social y económica. Barcelona, Ed. Vicens-Vives, 1974. (Ed. Bolsillo). v.IV, pp.102 ss.

Jurisconsulto, economista e político, Campomanes (1723-1803) foi presidente da "Real Academia de la Historia" (1764) e fiscal do "Real Consejo Supremo de Castilla" (1762), destacando-se no fomento da agricultura, da indústria e do comércio. Tomando parte com Aranda na expulsão dos jesuítas, utilizou o espólio bibliográfico destes para a criaçāo de bibliotecas em todo o reino. Nutria verdadeira aversāo à vagabundagem, que considerava um cancro nacional. Procurou reprimi-la com legislação apropriada e, também, com a reforma do ensino. Presidiu as Cortes de 1789 e obteve o restabelecimento do direito das'mtalheres na sucessäo ao trono, fato de larga repercussẩo na história espanhola. Em 1791, demitiu-se e retirou-se à vida privada. Três de suas obras são fundamentais para o estudo do período em questão: Vida y obras de Feijoo (1765); Discurso sobre el fomento de la industria popular (1774); Discurso sobre la educación popular de los artesanos y su fomento (1795).

${ }^{7}$ CABARRUS, Francisco. Cartas sobre los obstáculos que la naturaleza la opinión y las leyes oponen a la felicidad pública. Vitoria, (en la imprenta de don Pedro Real), 1808, p.32. Citado por SARRAILH, op.cit., p.80.

Natural da França (1752-1810), foi o principal conselheiro de Carlos III para assuntos econômicos. Fundou e dirigiu o Banco de S. Carlos (1782) e foi autor do projeto de criaçāo da Companhia de Comércio das Filipinas (1785). Partidário do direito de propriedade, do laissez-faire, da redução dos direitos aduaneiros e da liberdade de comércio, caiu em desgraça após a morte do rei. Foi preso em 1790 e libertado em 1792. Graças a Godoy, em 1797, foi nomeado embaixador na França. Colaboracionista durante as invasōes francesas, tornou-se impopular e perdeu a maior parte de seus amigos.

${ }^{8}$ ASSO, Ignacio de. Historia de la economía política de Aragón. Zaragoza, (por Fr. Mallón), 1798. /Reed. Zaragoza, Heraldo de Aragón, 1947. Com prólogo e indices de J.M. Casas Torres/. p.212.

Ignacio Jordán de Asso y Del Río fazia parte daquela minoria seleta que "ébrios de cultura, à semelhança dos homens do Renascimento, ativos, desinteressados, se impöern, por seu saber e por sua fô,, ao governo e à opiniẫo". (SARRAILH, op.cit., p.122)

CElebre como economista e como betánico, propugnou pelo livre comércio do trigo e pela reardenaçăo agrária da Espanha. Com significativo gesto, legou o seu magniffico herbário à Sociedade Econômica de Zaragoza. 
${ }^{9}$ ANES, Gonzalo. El antiguo régimen: los Borbones. Madrid, Alianza/Alfaguara, 1976, 2: ed., p.194.

10 Apud VICENS VIVES, op.cit., p.15.

11 WARD, Bernardo. Proyecto económico... Madrid, Ibarra, 1782, 3" ed., p.198 - Conforme registra SARRAILH, op.cit., p.755: "o Proyecto consiste em grande parte em uma reprodução de certos escritos de José de Campillo y Cosío".

${ }^{12} \mathrm{Cf}$. SARRAILH, op.cit., 9.81.

13 ANES, op.cit., p.20.

14 ANES, op.cit., p.28.

${ }^{15}$ VOLTES, Pedro. Carlos III y su tiempo. Barcelona, Ed. Juventud, 1975, p.186.

${ }^{16}$ BRAGANÇA, Isabel de Orleans e. Op.cit. Rio de Janeiro, Livraria Francisco Alves, 1983, p.71.

17JOVELLANOS, Gaspar Melchor de. Diarios. (Seleción). Madrid, Alianza, 1967, p.124; idem, Oviedo, Instituto de Estudios Asturianos, 1953-1956. 3v.; t.I, p. $475 ;$ t.II, p.87.

${ }^{18}$ TORRES VILLARROEL, Diego. Vida. Madrid, La Lectura, 1912. (Clśsicos Castellanos, $\mathrm{n}^{\circ}$ 7), pp.131-133.

${ }^{19}$ ISLA, José Francisco de. Historia del famoso predicador Fray Gerundio de Campazas. Madrid, (?), 1945. /Biblioteca de Autores Españoles, t.15, p.128.

O Pe. Isla (1703-1781), de família nobre, era dotado de prendas intelectuais excepcionais, que se-fizeram evidentes e públicas desde a mais tenra idade. Basta dizer que aos onze anos obteve o grau de bacharel em leis. Nutrindo pelos jesuítas, em princípio, acentuada antipatia, foi entre eles que professou, em 1719, aos dezesseis anos de idade. Desde entä́o, o seu devotamento à Ordem foi perfeito, indo às raias de um verdadeiro martírio, tanto físico como espiritual, nas horas trágicas da expulsấo da Espanha e da posterior supressāo da Companhia por Clemente XIV, em 1773. Terminou seus dias na Itália, cercado da maior consideração, quer por sua vida exemplar, quer pelo brilho de seu invulgar intelecto. Foi sem dúvida o escritor mais popular entre os espanhóis da segunda metade do século XVIII.

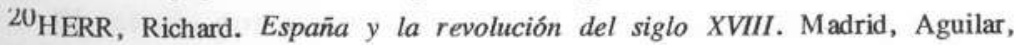
1973, p.19, nota 22.

${ }^{21}$ ARANGUREN, José Luis L. Moral y sociedad: la moral social española en el siglo XIX. Madrid, Cuadernos para el Diálogo, 1970, 4* ed., p.19.

${ }^{22}$ ARANGUREN, op.cit., p.19.

${ }^{23}$ ARANGUREN, op.cit., pp.19-20.

${ }^{24}$ SANCHEZ-DIANA, José María. El despotismo ilustrado de Federico el Grande y su influencia en España. In: ARBOR, XXVII, $\mathrm{n}^{\circ} 100$ (1954), pp.518-543.

25 A este propósito, Campomanes cunhou uma frase lapidar: "O verdadeiro estrangeiro em sua pátria é o ocioso”. Apud SARRAILH, op.cit., p.331.

${ }^{26}$ CAMPOMANES: Notas ao Dicurso VI do Memorial de Martínez de la Mata, in Apéndice a la Educación Popular, parte IV, pp.104-105; apud MUÑOZ PEREZ, José. La España de Carlos III y su conciencia de período histórico; in Estudios sobre historia de España. Madrid, Norte y Sur, 1965, p.366. 
27 Apud SARRAIl.H, op.cit., p.20.

28 ARANGUREN, op.cit., p.21.

${ }^{29} \mathrm{MUNNOZ}$ PEREZ, op.cit., p.363.

${ }^{30} V$.: FERRER DEL RIO. Historia del Reinado de Carlos III en España Madrid, Matute, 1856, 4v.; SANCHEZ AGESTA, Luis. El pensamiento polfico del despotismo ilustrado. Sevilla, Univ. de Sevilla (Col. Bolsillo), 1979; DOMINGUEZ ORTIZ, Antonio. La sociedad española en el siglo XVII. Madrid, CSIC, 1955; HAMILTON, Earl J. War and prices in Spain (1651-1800). Cambridge, Mass., Harvard University Press, 1947; GARCIA PEREZ, Guillermo. La economía y los reaccionarios al surgir la España contemporanea. Madrid, Cuademos para el Diálogo, 1974.

${ }^{31}$ VOLTES, op.cit., p.77.

${ }^{32}$ Cf. VOLTES, op.cit., p.137.

33 Apud VOLTES, op.cit., p.257.

${ }^{34}$ VOLTES, op.cit., p.259.

*Pontifícia Universidade Católica do Rio Grande do Sul Departamento de História CEP - 90.620 - Porto Alegre - RS 